\title{
REFLEKSI PADA RELASI ANTARA TEOLOGI DAN FILSAFAT DALAM PERSPEKTIF TEOLOGI INJILI
}

\author{
Bobby Kurnia Putrawan, ${ }^{1}$ Edi Sugianto, ${ }^{2}$ Yan Kristianus Kadang ${ }^{3}$ \\ ${ }^{1}$ STAPIN Majalengka, ${ }^{2}$ Sekolah Tinggi Teologi Tabernakel Surabaya, ${ }^{3}$ Institut Agama Kristen Negeri Toraja \\ Email: ${ }^{1}$ bkputrawan@gmail.com, ${ }^{2}$ esugianto.edu@gmail.com, ${ }^{3}$ yankadang07@gmail.com
}

\begin{abstract}
The pros and cons of philosophy and theology have a reputation in the history of Christianity. The importance of understanding philosophy and its importance can be explained correctly. Reflections on the relationship between philosophy and theology will help Christians sharpen and develop their theology, especially evangelical theology. Therefore, philosophy and theology need to be harmoniously correlated in knowing God through His truth, by always thinking of God and advancing God's word through the perspective of evangelical theology. Philosophy and theology are mutually reinforcing and sharpening. Meanwhile, the relationships offered are mutually constructive in their task as a means of knowing God and also to build insight into the evangelical Christian world.
\end{abstract}

Key Words: Relation, Philosophy, Theology, the Christian Worldview, Evangelical.

\begin{abstract}
ABSTRAK: Relasi pro dan kontra mengenai filsafat dan teologi telah tergores di dalam sejarah kekristenan. Pentingnya memahami filsafat dan teologi sangatlah penting, sehingga dapat merelasikan keduanya secara tepat. Refleksi terhadap relasi antara filsafat dan teologi akan membantu orang Kristen untuk menajamkan dan mengembangkan teologinya, khusus teologi injili. Oleh sebab itu, filsafat dan teologi perlu direlasikan secara harmonis di dalam mengenal Allah melalui kebenaran-Nya, dengan senantiasa bersikap takut akan Allah dan menghargai firman Allah melalui perspektif teologi injili. Keilmuan filsafat dan teologi saling menguatkan dan menajamkan. Adapun relasi yang dimaksud ialah keduanya digunakan saling membangun dalam tugasnya sebagai sarana pengenalan akan Allah serta sebagai kerangka untuk membangun wawasan dunia Kristen yang injili.
\end{abstract}

Kata Kunci: Relasi, Filsafat, Teologi, Wawasan Kristen, Injili.

\section{PENDAHULUAN}

Hubungan antara filsafat dan teologi akan terus menjadi pertanyaan yang hangat diperdebatkan di antara orang-orang Kristen, namun keduanya merupakan konstitutif untuk kerangka kerja di mana pemikiran mereka berkembang. Para ahli filsafat dan ahli teologi (filsafat Kristen) tampaknya telah menemukan modus vivendi untuk koeksistensi kedua disiplin ilmu tersebut (Peperzak, 1997, p. 321). Filsafat dipandang sebagai sesuatu yang menyesatkan oleh mereka yang anti-filsafat. Geisler dan Feinberg (2002) menuliskan bahwa ada yang menggangap filsafat sebagai alat Iblis, yaitu dengan menggemakan pertanyaan Tertullianus, "Apakah hubungan antara Atena dengan Yerusalem?" Diller mengutip Barth bahwa secara umum Karl Barth dengan tegas menolak kegunaan filsafat bagi teologi. Barth menjelaskan bahwa dalam teologinya ia tidak banyak menggunakan fil- safat. Dia menganggap teologi filosofis sebagai penyembahan berhala dan itu mengenai filosofi agama (Diller, 2010, p. 1025).

Selain itu, Geisler dan Feinberg (2002) menambahkan bahwa beberapa orang juga beranggapan bahwa filsafat adalah bidang teologi karena melihat tugasnya sebagai penyusun argumentasi-argumentasi untuk mempertahankan agama Kristen. Penulis mengamati bahwa salah satu dampak dari pandangan tersebut ialah adanya kalangan gereja yang anti dengan pendidikan teologi (sekolah tinggi teologi), serta beranggapan bahwa Sekolah Alkitab-lah yang lebih murni memegang kebenaran Firman Tuhan. Berkaitan dengan kalangan yang anti-filsafat dan teologi, Brown (1994) juga mengatakan bahwa ada kelompok tertentu dalam kekristenan yang menolak filsafat dengan menyatakan bahwa filsafat sebagai 
satu hal yang membuat sebagian orang Kristen ragu dan ada dalam permainan api yang membahayakan.

Sebenarnya apakah memang filsafat dan teologi adalah sesuatu yang jahat, sesuatu yang salah, sesuatu yang sesat dan sangat bertentangan dengan iman Kristen, sehingga membuat beberapa kalangan menentangnya? Geisler dan Feinberg (2002) kembali menegaskan bahwa, sebagian para pelajar atau orang Kristen kemungkinan belum memahami makna sebenarnya dari filsafat, sebab memang faktanya filsafat hampir tidak pernah dipelajari sebelum seseorang menginjakkan kaki di perguruan tinggi. Alasan ini sangat masuk akal sebab pada umumnya, pada umumnya filsafat masih belum dipelajari di dalam sekolah Alkitab, dan filsafat mulai diajarkan pada saat memasuki dunia sekolah tinggi teologi.

Namun demikian, terlepas dari mulai dipelajarinya filsafat dalam pendidikan, maka jika ada yang mempersoalkan tentang filsafat, hal tersebut pasti memiliki sebab-musababnya. Tidak dapat disangkal, bahwa di dalam sejarah, filsafat dan teologi itu sendiri juga terdapat ketegangan yang luar biasa, bahkan juga pernah memunculkan perbedaan-perbedaan pandangan (Reynold, 2009, pp. 16-22). Bahkan di permulaan kekristenan bagaimana pengaruh filsafat Plato berpengaruh terhadap perkembangan teologi pada bapa-bapa gereja terdokumentasi dengan baik, khususnya abad keempat dan kelima mengenai sifat trinitas, seperti the Apology of Aristides dan the Epistle to Diognetus (Gaston, 2009, p. 576; Santrac, 2013, p. 2). Jadi, yang menjadi pokok permasalahan dalam pembahasan ini adalah bagaimana merefleksikan relasi antara filsafat dan teologi? Sedangkan tujuan penulisan ini adalah mengetahui refleksi relasi antara filsafat dan teologi dalam perspektif teologi injili.

\section{METODE}

Pada tulisan ini, penulis menggunakan pendekatan kualitatif deskriptif, maka penulisan ini menggunakan metode deduktif yang bersifat sistematis, kritis, dan analitis. yang menekankan pada relasi antara teologi dan filsafat, dan diakhir dengan memberikan refleksi pada kesimpulan di artikel ini (Rahmat, 2009, p. 2; Susilowati, 2017, p. 50). Dengan kata lain, dengan pendekatan kualitatif deskriptif, maka sumber relasi filsafat dan teologi dari pelbagai literatur diantaranya Adriaan Theodoor Peperzak (Philosophia), Colin Brown (Filsafat \& Iman Kristen), Kevin Diller (Karl Barth and the Relationship Between Philosophy and Theology), $\mathrm{Pa}-$ wel Rojek (Intelectus Quaerens Fidem), B.B. Warfield, W.A. Brown dan Gerald B. Smith (The Task and Method of Systematic Theology). Kemudian merefleksikan tulisan ini, penulis memakai buku Ronald Nash (Iman \& Akal Budi), David A. Noebel (The Battle for Truth: Defending the Christian Worldview in the Marketplace of Ideas) dan artikel Cathal Doherty (The Symbiosis of Philosophy and Theology in Blondel's Supernatural Hypothesis) dan beberapa sumber literatur tambahan lainnya untuk memperkaya artikel ini.

\section{HASIL DAN PEMBAHASAN}

\section{Sejarah Perkembangan Relasi Filsafat dan Teologi.}

Secara etimologis kata "filsafat" berasal dari bahasa Yunani $\phi \imath \lambda o \sigma o \phi \imath \alpha$ (philosophia), yang terdiri dari kata $\varphi \imath \lambda o$ (philo), yang berarti 'mencintai' dan kata $\sigma o \varphi \imath \alpha$ (sophia), yang berarti bijaksana. Dengan demikian kata philosophia berarti 'cinta kebijaksanaan'. Konsepnya adalah neologisme yang dikaitkan dengan Pythagoras. Dengan demikian Phytagoras menghadirkan filsafat sebagai suatu yang tinggi dan menjadi pencapaian tertinggi manusia, dan seorang filsuf sebagai pendukung kebijaksanaan. Jadi filsafat menyiratkan baik dalam proses mempertanyakan sampai dengan hasil mempertanyakan sebagaimana diwujudkan dalam usaha secara pribadi atau non-pribadi yang bernilai bagi umat manusia. Sebagai disiplin akademis, filsafat mendidik-melatih prinsip-prinsip akal dan logika dalam upaya untuk memahami realitas dan menjawab pertanyaan mendasar tentang pengetahuan, kehidupan, moralitas, dan sifat manusia serta melakukannya (Anthony, 2014, 
p. 87; Michaud, 2015, p. 74; Peperzak, 1997, pp. 322-323).

Menurut Knight (2006, p. 153), dalam sistematika filsafat, terdapat tiga kategori dasar yang sering digunakan, yaitu: metafisika, epistemologi, dan aksiologi. Pertama, kategori metafisika selalu berkaitan dengan sifat dari hakikat sesuatu yang ada, yaitu keberadaan alam dan makna dari realitas. Dalam kategori ini terbagi ke dalam 4 aspek, yaitu: kosmologi (tentang dunia), teologi (tentang Allah), antropologi (tentang manusia), dan ontologi (tentang yang ada/keberadaan). Kedua, kategori epistemologi berkaitan dengan pengetahuan dan kebenaran tentang hal yang diketahui dan cara untuk mengetahuinya. Adapun sumber kebenaran di dalam kategori ini adalah Tuhan dan Alkitab; pancaindra (sense); rasio (reason); otoritas (expert); intuisi (personal insight); dan sumber pengetahuan yang melengkapi. Ketiga, kategori aksiologi berkaitan dengan nilai dan manfaatnya. Dalam kategori ini, biasanya mencakup etika dan estetika.

Melalui filsafat manusia dibawa kepada pemikiran yang kritis dalam meresponi berbagai hal hingga mendapatkan jalan keluar sampai kepada kesimpulannya. Sehingga, Michaud mengatakan ketika manusia berfilsafat maka ia sedang berpikir rasional (logis, kristis, dan sistematis), komprehensif, dan bertanggung jawab. Berfilsafat meningkatkan berpikir kritis, penyelesaian masalah yang fleksibel, dan pembelajaran berbasis inkuiri adalah manfaat yang mungkin tidak terbatas pada filsafat itu sendiri dalam diri manusia. (Macintyre, 2009, pp. 179-196; Michaud, 2015, pp. 74-75; Peperzak, 1997, p. 323). Oleh sebab itu, seorang dikriteriakan berfilsafat apabila orang tersebut sanggup berpikir secara demikian. Itu merupakan pemikiran yang sangat ideal terkait dengan filsafat.

Mengacu kepada definisi di atas, maka filsafat telah ada sejak manusia ada. Allah telah menciptakan manusia serupa dan segambar dengan Dia, yang mana di dalamnya terdapat juga cinta dan akal budi (Kej. 1:26-28). Dengan cinta dan akal budi, manusia berusaha memahami hal-hal apa yang ada, ba- ik di dalam maupun di luar dirinya. Sehingga filsafat telah ada dan terus berkembang di dalam sejarah peradaban manusia dari awal hingga saat ini, bahkan akan terus ada selama manusia itu ada. Catatan sejarah peradapan manusia di dunia menunjukkan bagaimana manusia telah berfilsafat. Di dalam Alkitab, khususnya Perjanjian Lama, tokoh yang identik dengan hal ini adalah Raja Salomo. Tulisan di dalam kitab Pengkhotbah dengan sangat jelas menjelaskan bagaimana Salomo, menyelidiki tentang segala sesuatu di bawah matahari, dan kemudian membuat suatu kesimpulan, bahwa segala sesuatu adalah sia-sia jika di luar sikap yang takut akan Allah.

Namun demikian, bila mengikuti konsensus yang ada, filsafat diyakini lahir pada abad ke-6 sM, yang diawali oleh seorang filsuf bernama Thales dari Miletus, di Asia Kecil. Aristoteles menyebut Thales (624-546 sM) sebagai bapak filsafat sebab kegiatan berfilsafatnya mencoba menjelaskan dunia dan gejala-gejala yang ada di dalamnya dengan rasio manusia, tidak seperti orang-orang yang telah ada sebelumnya yang bersandar pada mitos (Hadiwijono, 2014, p. 16; Stumpf, Samuel Enoch; Fieser, 2003, p. 7). Dengan demikian, seperti pengertian etimologi filsafat, maka asal-muasal filsafat adalah dari Yunani.

Selanjutnya filsafat tersebut dikembangkan oleh generasi-generasi berikutnya, yang disebut filsuf (sophists). Filsuf Yunani yang terkenal selanjutnya adalah Protagoras (490-420 sM), Sokrates (470399 sM), kemudian muridnya Plato (427-347 sM), lalu muncul murid Plato, Aristoteles (384-322 sM), dan Epikuros (342/341-270 sM). Orang-orang ini telah menjadi figur yang paling berpengaruh di dalam dunia filsafat. Setelah itu filsafat berkembang dengan begitu pesatnya dan menghasilkan berbagai penemuan dan pengembangan dalam pelbagai bidang (Stumpf, Samuel Enoch; Fieser, 2003, pp. 31-124).

Walaupun kata filsafat berasal dari bahasa Yunani, namun bukan berarti hanya orang Yunani saja yang berfilsafat, melainkan juga bangsa-bangsa lain, sebab setiap manusia memiliki potensi untuk berfilsafat. Misalnya, wilayah lain seperti salah satunya di China muncul filsuf bernama Konfusius (551- 
479 sM). Dan tentunya sistem berfilsafat juga terjadi di belahan bumi yang lain yang dilakukan oleh manusia. Sebab sejatinya, perlu ditegaskan bahwa berfilsafat itu identik dengan keberadaan manusia sebagai ciptaan Tuhan.

Secara umum, Hadiwijono (2014, pp. 7-9) mengatakan sejarah filsafat dibagi ke dalam beberapa kelompok masa, yaitu: zaman kuno (600sM-500M); zaman abad pertengahan (500-1500 M); zaman modern dalam pembentukaannya (1500-1900 M); dan zaman kontemporer/postmodern (1900-2000). Pada zaman kuno terdapat masa pra-sokrates, masa Sokrates, Plato, dan Aristoteles, masa Helenis Romawi, serta masa patristik. Kemudian pada abad pertengahan lebih banyak berbicara tentang teologi dan alam. Lalu pada zaman modern, muncul masa renaisans, modern awal dan pencerahan. Sedangkan pada zaman kontemporer lebih kepada pendikotomian antara logis dan spekulatif.

Pada sejarah perkembangan filsafat saat ini, telah bermunculan para filsuf dari berbagai belahan dunia dari generasi ke generasi dalam memahami tentang Tuhan, manusia, dan alam sekitarnya. Kemudian, hasil pemikiran filsuf satu dengan yang lain, seringkali saling melengkapi, namun tidak sedikit juga yang bersebrangan. Hal tersebutlah yang kadangkala memberikan image yang kurang baik tentang filsafat. Dalam perkembangannya, filsafat memiliki banyak sekali cabang-cabangnya. Adapun cabangcabang utama filsafat tersebut ialah: etika, logika, epistemologi, metafisika, logika, sejarah, agama, dan lainnya. Bahkan setiap disiplin seringkali memiliki filsafatnya masing-masing. Selain itu, masing-masing memiliki pembahasan dan tantangan-tantangannya sendiri-sendiri.

\section{Relasi Antara Filsafat dan Teologi}

Seperti yang diungkapkan pada bagian pendahuluan di atas, bahwa seringkali dalam kalangan tertentu, teologi dipahami sebagai sesuatu yang menyesatkan, sesuatu yang bebas, sesuatu yang tidak murni dari kebenaran Firman Tuhan (Alkitab). Pemahaman tersebut muncul, sebab tidak dapat pung- kiri akan adanya fakta beberapa mereka yang belajar teologi justru semakin tidak mempercayai Alkitab yang tanpa salah, bahkan ada yang menjadi ateis atau berpindah kepada kepada kepercayaan yang lain. Selain itu, kondisi tersebut juga dilatar-belakangi oleh pemahaman bahwa di dalam Teologi telah dimasuki ilmu-ilmu filsafat yang meragukan Alkitab dan keberadaan Tuhan. Apakah memang sejatinya teologi dipahami demikian?

Pada dasarnya, istilah teologi berasal dari dua kata kata $\theta \varepsilon o s$ (theos), artinya Allah dan $\lambda o \gamma o s$ (logos) artinya pemikiran, uraian, ilmu (Lukito, 2002, p. 11; Ronda, 2005, p. 12). Sehingga teologi dapat didefinisikan sebagai ilmu tentang Allah atau pelajaran dan penjelasan tentang Allah. Sedangkan secara umum, teologi adalah ajaran tentang Allah dan karya-karya-Nya (Erickson, 1999, p. 22). Kemudian penulis memahami bahwa 'Teologi' merupakan suatu usaha manusia (ilmu) yang menyelidiki tentang Allah dalam hubungan-Nya dengan alam semesta, yang mendasarkan penyelidikannya melalui penyataan umum (ciptaan) dan penyataan khusus (Alkitab) melalui interpretasi teks ke dalam konteks kehidupan umat manusia.

Dalam perkembangannya, teologi juga mengalami pasang surut. Teologi secara praktis telah dimula dari tokoh-tokoh Perjanjian Lama yang membahas tentang Allah. Selanjutnya, masuk ke dalam dunia Perjanjian Baru dan zaman bapak-bapak Gereja; kemudian zaman reformasi; pencerahan, modern dan post-modern. Masing-masing zaman memiliki tantangan tersendiri. Pada umumnya teologi yang berkembang setiap jaman juga dipengaruhi oleh perkembangan yang ada di dalam zaman itu. Singkatnya, perkembangan yang terjadi di dalam dunia, mempengaruhi metode dan sistem penyelidikan (hermeneutik) Alkitab sebagai Firman. Ada kalanya Alkitab menjadi satu-satunya kebenaran yang mutlak, namun tidak jarang Alkitab hanya sekedar buku biasa dan di bawah dari rasional manusia. Jadi, pemahaman akan Alkitab serta metode hermeneutik yang digunakan di dalam memahaminya, akan selalu menjadi dasar dibangunnya sebuah teologi. Sehingga per- 
kembangan teologi di pengaruhi oleh sikap seorang teolog kepada Alkitab dan bagaimana ia memahaminya.

Dari pemahaman-pemahaman di atas, sebenarnya semua hal yang membahas tentang Allah dapat dikatakan teologi. Dan mereka yang melakukannya adalah seorang Teolog, yang sedang berteolog (termasuk mereka yang awam dan juga yang "sekolah Alkitab" non-STT). Sehingga dapat dikatakan bahwa ketika manusia berusaha untuk berpikir dan memahami tentang Allah dan yang behubungan dengan Dia, maka pada saat itu mereka sedang berteologi. Oleh sebab itu, secara praktis teologi telah ada sejak manusia ada dan terus ada selama manusia berusaha memahami tentang Tuhan. Dengan demikian, sejauh ini dapat dikatakan bahwa tidak seharusnya mempermasalahkan tentang istilah teologi, namun lebih kepada bagaimana seorang teolog berteologi.

Berdasarkan pemahaman akan filsafat dan teologi yang telah disampaikan di atas, maka terdapat titik perbedanaan dan titik temu di antara keduanya. Perbedaannya adalah masalah penekanan. Meskipun filsafat dimulai dari studi tentang alam, dan teologi dimulai dari mendengarkan wahyu (Alkitab), keduanya bergerak ke tujuan akhir yang sama, yang merupakan kebijaksanaan universal tertinggi. Studi tentang makhluk dengan mudah menuntun pada penemuan sumber utamanya, dan penyelidikan keilahian memberi cahaya pada seluruh alam semesta. Zaman modern memunculkan pemisahan di antara mereka. Akibatnya, kami tiba di proyek filsafat alam murni di satu sisi, dan gagasan teologi murni mengungkapkan di sisi lain. Yang cukup menarik, dalam kedua kasus itu, teologi kehilangan: dalam kisah yang pertama, hal itu menjadi sia-sia, yang belakangan tidak berarti. Namun demikian, setidaknya ada dua cara yang berbeda di mana seseorang dapat memulihkan hubungan antara teologi dan filsafat. Pertama, filsafat dapat masuk ke dalam bidang teologi untuk memberinya beberapa konsep dan prinsip dan upaya untuk membenarkan klaimnya; kedua, teologi dapat mengintervensi dalam ranah filsafat, menyarankan kepadanya beberapa masalah, kategori, dan klaim untuk diterapkan pada dunia alami. Proyek pertama kira-kira bisa disebut teologi filosofis, sementara yang lain bisa disebut filsafat teologis (Rojek, 2016, p. 149; Tety \& Wiraatmadja, 2017, p. 57). Titik temunya yaitu pada saat keduanya sama-sama berusaha untuk memahami tentang Kebenaran Allah yang sejati. Itulah relasi positif keduanya. Sedangkan relasi negatif yang sama adalah ketika masing-masing tidak menuju kepada Allah yang sejati. Pemahaman akan sisi negatif dan positif pun memiliki variasi, sebab dari perspektif mana seseorang melihat. Dalam pembahasan ini, lebih melihat dari sudut pandang Injili konservatif.

Reynold (2009, pp. 18-21) menyatakan bahwa sejarah telah mencatat tentang hubungan antara teologi dan filsafat telah memiliki perseteruan yang berlangsung cukup lama, bahkan telah terdapat usaha berulang-ulang untuk membangun tembok dikotomi antara keduanya. Hal tersebut sepertinya didasari pada teks Alkitab yang telah dikutip pada awal pembahasan ini, yaitu dalam Kolose 2:8. Selain itu juga didasarkan pada pernyataan Bapa Gereja, Tertulianus (160-225 M), yang telah disinggung di atas bahwa apakah hubungan antara Yerusalem (tempat firman TUHAN berasal) dan Athena (tempat filsafat berasal). Pada zaman reformasi, gereja-gereja reformatoris juga diperhadapkan dengan bermacam-macam tantangan, salah satu tantangannya adalah menghadapi perkembangan pemikiran filsafati, yang makin lama makin memusuhi pemikiran Kristiani (Hadiwi-jono, 2014, p. 6). Holmes (2009, pp. 33-35) mengatakan dalam perkembangannya, tidak sedikit juga, bahwa orang percaya memiliki konsep pemahaman yang mendikotomikan antara yang "sakral (hal-hal spiritual dan religius)" dengan yang "sekuler (hal-hal sementara yang ada di dunia)". Teologi di anggap sebagai suatu yang sakral, sedangkan filsafat di-anggap sebagai sesuatu yang sekuler.

Hal senada juga disampaikan oleh Tong, yaitu bahwa relasi antara filsafat dan iman Kristen (teologi) menjadi salah satu bidang sejarah yang pa- 
ling kontroversial dan paradoks. Sebab, beragam pendapat bahwa filsafat merupakan musuh Kristen mendapat dukungan, sedangkan pendapat yang mengatakan filsafat tidak perlu dipertentangkan dengan iman Kristen juga mendapat dukungan. Dengan demikian problemanya terletak pada apakah definisi filsafat dan seperti apakah filsafat yang benar. Oleh sebab itu, Geisler dan Feinberg (2002, p. 3) juga menyampaikan bahwa sepanjang sejarah, terdapat hubungan "benci tapi rindu" antara filsafat dengan Agama Kristen dan Teologi Kristen. Keduanya nampaknya terpisah, namun sebenarnya mereka juga perlu dipersatukan. Tidak dapat dipungkiri bahwa memang sejarah pernah mencatat ada filsuf-filsuf yang bersebrangan dengan Teologi (iman Kristen), namun ada filsuf-filsuf yang justru senada dengan teologi.

Sistem filosofis besar, seperti teori ide Plato, metafisika Aristoteles, atau bahkan sistem Descartes, Kant dan Hegel, semuanya merupakan ekspresi filosofis dari pengalaman utama iman para penemu mereka. Bahkan filosofi ateistik dipengaruhi oleh agama, karena "negasi Allah juga semacam agama, setidaknya dalam pengertian psikologis." Rojek (2016, p. 154) menjelaskan tulisan Florovsky yang mengatakan pemikir yang beriman harus setia menjaga perbatasan antara divina dan humana, antara Yang Transenden dan Yang Imanen, tetapi ia tidak bisa, seharusnya tidak dan bahkan tidak dapat melihat dunia, memikirkannya dan menjelaskannya seolah-olah tidak ada Tuhan. Karena Tuhan benar-benar ada, mata agama langsung memandang-Nya di mana-mana, dan pengalaman kebebasan beragama mencakup semua sifat orang percaya. Di tingkat pribadi, iman selalu masuk ke dalam filsafat, dan tidak mungkin mengusirnya. Ternyata iman dan nalar berbeda, tetapi tidak sepenuhnya terpisah. Meskipun iman bersifat otonom sehubungan dengan akal, akal tidak otonom sehubungan dengan iman. Karena itu, pengalaman iman dapat mengubah sikap seseorang terhadap kenyataan, tetapi juga mampu mengubah seluruh pandangan dunia seseorang, dan menembus sistem kepercayaan filosofis seseorang. Memang, filosofi seperti itu tidak hanya menjadi pembenaran agama, tetapi lebih merupakan ekspresi dari keyakinan seseorang (Peperzak, 1997, pp. 326-329).

Hal tersebut menunjukkan bahwa telah terjadi ketegangan antara filsafat dan teologi di dalam sejarah pemikiran Kristen. Walaupun keduanya juga pernah diusahakan untuk bersama, Dengan demikian, perlu memahami dengan jelas dan tepat prinsip dasar dari filsafat maupun teologi itu sendiri, sehingga dapat menemukan relasi yang harmonis di antara ke duanya, secara khusus di dalam proses pengenalan akan Allah, yang adalah sumber kebenaran sejati. Sebab diyakini, keduanya adalah hal yang baik dari Tuhan.

\section{Filsafat dan Teologi sebagai sarana Mengenal Allah}

Filsafat dan Teologi sekalipun dalam sejarah menunjukkan adanya hubungan "benci tetapi rindu", bahkan ada sebagian orang menentang kedua-duanya di dalam kaitannya dengan Alkitab, namun kedua hal tersebut adalah sesuatu yang seharusnya dapat digunakan secara bersama-sama dalam memahami tentang Allah. Kondisi itu dapat dipahami dari prinsip-prinsip yang terkandung di dalam kedua hal tersebut.

Filsafat dipahami sebagai "cinta akan hikmat atau kebijaksanaan". Hikmat atau kebijaksanaan itu sendiri berarti kebenaran yang sejati. Dari pemahaman ini, maka filsafat selaras dengan Alkitab, yaitu seperti yang dikatakan oleh pe-amsal: "Janganlah meninggalkan hikmat itu, maka engkau akan dipeliharanya, kasihilah dia, maka engkau akan dijaganya!" (Ams. 4:6). Apa yang dinasihatkan penulis Amsal ini merupakan bentuk dari nasihat untuk berfilsafat. Dengan demikian, orang percaya sudah seharusnya berfilsafat dengan benar. Pengkhotbah sendiri bersifat filosofis, dan mengungkapkan beberapa pandangan filosofis duniawi sebelum mencapai konklusi bahwa filsafat yang terbaik adalah didasarkan pada yang takut akan Allah dan menaati-Nya (Pkh. 12:13) (Noebel, 2001; Waltke, 2004, p. 101). Salomo juga menyampaikan bahwa takut akan TUHAN merupakan awal dari pengetahuan dan hikmat (Ams. 1:1-7; 9:10). Dengan demikian, berfilsafat berarti 
ada kaitannya dengan TUHAN Allah, atau dengan kata lain untuk berfilsafat yang benar harus didasarkan takut akan Allah. Jika memakai istilah Petrus, maka ini senada dengan “... kuduskanlah Kristus di dalam hatimu sebagai Tuhan..." (1 Ptr. 3:15). Biarlah Kristus yang menjadi tuan atas usaha filsafat, dan bukan yang lain.

Sedangkan Teologi dimengerti sebagai "ilmu tentang Allah dan hal-hal yang berkaitan dengan-Nya". Namun pemahaman akan Allah ini sejauh mana Ia menyatakan diri kepada manusia untuk dapat diketahui, sebab Ia adalah Pencipta dan manusia adalah ciptaan-Nya. Di dalam sejarah, Allah telah menyatakan diri-Nya melalui wahyu umum dan wahyu khusus. Pemahaman dan pengenalan yang benar tentang Allah perlu dimiliki, sebab hal itu akan mendatangkan kehidupan shalom bagi manusia (Hos. 4:6; Kel. 29:45-46; Yer. 31:33-34). Mengenal Tuhan berarti memiliki pengertian, dan juga kehidupan (Ams. 9:10; 1 Yoh. 5:20).

Filsafat dan teologi memiliki prinsip-prinsip dasar yang sama, sebab keduanya sama-sama merupakan suatu ilmu. Adapun persamaan-persamaanya tersebut sebagai berikut minimal terdapat 4 poin. Pertama, keduanya sama-sama memiliki subyek yang sama, yaitu "Manusia" yang adalah pelaku sebagai filsuf dan juga sebagai teolog. Manusia diciptakan serupa dan segambar dengan Allah, sehingga mereka memiliki kemampuan untuk berfilsafat dan berteologi. Manusia bernalar, berperasaan, dan berkehendak, sehingga disadari atau tidak, mereka sedang menjadi subjek dari filsafat dan teologi. Filsafat dan teologi sama-sama membawa manusia untuk memaksimalkan keseluruhan yang ada di dalam dirinya. Bahkan seharusnya dapat dikatakan seorang teolog juga ada filsuf dan sebaliknya.

Kedua, filsafat dan teologi membahas objek yang sama, yaitu Allah dan hal-hal yang berkaitan dengan karya-Nya. Sepanjang sejarah filsafat dan teologi, mereka membahas tentang Allah, manusia, dan alam sekitarnya. Hal tersebut menunjukkan bahwa filsafat dan teologi memiliki objek, serta ruang lingkup yang sama. Selanjutnya, filsafat dimulai dari rasa ingin tahu akan kepastian (Suriasumantri, 2009, p. 19). Sehingga dengan filsafat akan mendorong manusia untuk mengetahui apa yang diketahui dan apa yang belum diketahuinya tentang objek yang sedang dimaksud di atas. Hal ini berfilsafat berarti bahwa seorang filsuf perlu merendahkan hati sebab tidak semua hal akan dapat pernah diketahui secara sempurna, sebab ada hal-hal yang di luar batas manusia. Dengan demikian, berfilsafat juga berarti berinstropeksi diri untuk menyatakan kebenaran sejauh mana yang telah dipahami. Hal yang sama juga ada di dalam Teologi, yaitu bahwa seorang teolog hanya dapat memahami Allah sejauh mana Ia menyatakan diri-Nya. Sebab manusia adalah ciptaan yang terbatas, maka tidak dapat mungkin memahami Allah sebagai Pencipta yang tidak terbatas. Sehingga seorang teolog juga perlu merendahkan diri untuk mendapatkan pemahaman dari Allah.

Ketiga, keduanya juga memiliki tujuan yang sama, yaitu sama-sama mencari suatu kebenaran sejati. Dan sumber kebenaran adalah Allah, yang mana Ia telah menyatakan kebenaran-Nya di dalam wahyu umum dan wahyu khusus. Filsafat bertujuan untuk menemukan kebenaran sejati dan memberikan jawaban yang solutif terhadap permasalahan manusia. Filsafat memiliki tugas untuk melakukan suatu analisis deskriptif dan kritis untuk tindakan, isi dan praanggapan kepercayaan (Brown, 1994, p. 209). Seperti Wippel (1984, p. 209) memandang Aquinas, salah satu alasan ketidaksepakatan mengenai interpretasi yang tepat dari pemikiran Aquinas karena dia tidak berbicara banyak tentang masalah Filsafat Kristen. Namun, dia banyak bicara tentang hubungan antara iman dan akal. Dan dalam karyanya sendiri sebagai seorang teolog profesional, ia mengembangkan filosofi yang sangat canggih. Seseorang dapat belajar dari Aquinas tidak hanya dengan mengamati apa yang dia katakan tentang masalah alasan iman, tetapi juga dengan mempertimbangkan dengan hatihati apa yang dia lakukan - prosedur yang dia ikuti dalam mengarahkan dirinya ke topik-topik yang menarik secara filosofis. Dalam hal ini berhubungan dengan pengenalan akan Allah. Teologi juga bertu- 
juan untuk menemukan kebenaran tentang Allah. Hadiwijono (2014, p. 1) mengungkapkan bahwa ilmu teologi merupakan usaha manusia dengan akalnya untuk meneliti Alkitab, agar dapat mengetahui kebenaran-kebenaran ilahi. Dalam konteks ini, tugas teologi adalah menarik implikasi dari rangkaian peristiwa dalam urutannya, dan dalam kulminasinya dalam penampakan Kristus. Atau, sekali lagi, wahyu dapat diadakan untuk memasukkan komunikasi langsung kebenaran melalui organ-organ terpilih dari Roh ilahi. Kemudian, tugas mendasar dari teologi menjadi kepastian, perumusan, dan sistematisasi kebenaran yang dikomunikasikan, dan jika kebenaran ini sampai padanya diperbaiki dalam catatan tertulis yang berwibawa, jelas bahwa tugasnya sangat difasilitasi (Warfield, Benjamin B.; Brown, William Adams; Smith, 1910, p. 198). Selain itu, teologi juga memiliki tugas memindahkan atau mengangkat kesaksian Alkitab tentang penyataan atau wahyu Ilahi pada zaman dahulu kepada zaman sekarang (Hadiwijono, 2014, p. 2). Jadi, dua-duanya sama berusaha untuk mengungkapkan kebenaran yang sejati, dan kebenaran yang sejati tersebut bersumber dari Allah.

Dan yang keempat, keduanya memiliki metode dalam mengusahakan pencapaian tujuannya, sebab sama-sama sebagai ilmu. Nash mengatakan bahwa meskipun keduanya sering menggunakan bahasa yang berbeda dan sering mendatangkan kesimpulan yang berbeda, baik filsafat maupun agama harus berurusan dengan pertanyaan yang sama, yaitu meliputi pertanyaan-pertanyaan yang berkenaan dengan apa yang eksis (metafisik), bagaimana manusia harus hidup (etika), dan bagaimana manusia mengetahui (epistemologi) (Nash, 2013, p. 38). Ada metodemetode yang dimiliki oleh filsafat maupun teologi di dalam tujuannya mencari kebenaran. Namun hal itu tidak dibahas dalam pembahasan ini.

Dengan demikian, filsafat dan teologi keduanya merupakan sarana untuk mencari kebenaran yang sejati. Yang mana, kebenaran tersebut kembali kepada Allah, sehingga manusia dapat mengenalNya dan mendapatkan kehidupan. Akhirnya, memang Alkitab pernah mencatat akan nasihat agar berhati- hati dengan filsafat (Kol. 2:8), namun perlu diperhatikan bahwa jika ada filsafat yang kosong, tradisi dan yang tidak menurut Kristus, maka sudah tentu juga akan ada filsafat yang berisi dan yang tunduk kepada Kristus. Sebab berfilsafat yang benar akan membawa manusia kepada kebenaran Allah, dan kuncinya terletak pada kewaspadaan dan kesadaran manusia yang hidup berdasarkan Injil, sehingga dapat dikatakan bahwa segala kebenaran adalah kebenaran Allah yang ada dalam Injil (Platinga, 1999, p. 9). Berfilsafat dalam Injil inilah yang dapat digunakan untuk memahami Allah bersama-sama dengan teologi. Sekali lagi dapat dikatakan, seorang teolog sekaligus adalah filsuf dan begitu juga sebaliknya.

Kebersamaan teologi dan filsafat di dalam memahami tentang Allah, dapat saling melengkapi. Pada umumnya, teologi lebih berfokus kepada Alkitab sebagai wahyu khusus Allah, namun filsafat lebih luas lagi yaitu hingga kepada wahyu umum Allah. Dan di dalamnya ada kebenaran, yang bersumber dari Allah, sebab segala kebenaran adalah kebenaran Allah. Melalui wahyu umum, manusia dapat mengenal Allah, namun akan lebih sempurna bila mengenal-Nya melalui wahyu khusus. Alkitab berisi tentang filsafat, namun Alkitab bukan buku filsafat. Akhirnya, di dalam teori dan praktiknya, sudah seharusnya teologi dan filsafat bersama-sama digunakan sebagai sarana untuk mengenal dan hidup di dalam Allah (Brandt et al., 2018, pp. 151-152; Tety \& Wiraatmadja, 2017, p. 56). Dengan kata lain, filsafat membentuk menajamkan dan mengembangkan keilmuan teologi dengan mempertanyakaan keberadaan setiap objek teologi (ontologi), siapa teologi (epistemologi), dan bagaimana teologi bagi orang Kristen dan dunia (aksiologi).

Terlihat bahwa imajinasi filosofis barat didominasi oleh cara pertama. Tugas filsafat biasanya dilihat sebagai penyelidikan independen yang tidak didasarkan pada kebenaran yang diungkapkan, akhirnya memuncak dalam teologi alamiah, yang merupakan pembenaran filosofis dari beberapa klaim teologis dasar. Namun, ada juga cara kedua dalam melakukan filsafat, yang dimulai dengan wahyu (Al- 
kitab) dan kemudian mendekati dunia alami (Rojek, 2016, p. 149).

Kemungkinan dan kebutuhan akan usaha filosofis semacam itu baru-baru ini ditunjukkan oleh Macintyre (2009, p. 166): "Penyelidikan filosofis dimulai dengan mempertimbangkan bagaimana memahami urutan segala sesuatu dengan benar dan dengan demikian bergerak dalam penyelidikannya untuk menegaskan keberadaan Tuhan." Tetapi penyelidikan filosofis menemukan awal yang kedua dalam mempertimbangkan bagaimana umat Kristen perlu memahami urutan hal-hal dalam terang pewahyuan diri Allah. Jadi, filosofi dan teologi masing-masing membutuhkan dan saling melengkapi. Dalam hal pertama, filosofi mencoba membangun kembali kepercayaan agama yang rasional, ia menyediakan konsep dan prinsip untuk teologi (intellectus quaerens fidem). Dalam yang kedua, sebaliknya, wahyu (Alkitab) menyarankan kategori dan prinsip dimana dunia alami dapat dijelaskan dan dijelaskan (fides quaerens intellectum). Yang pertama adalah jalan teologi filosofis, yang terakhir adalah jalan filsafat teologis. Kedua gerakan tersebut merupakan program integral dari filsafat Kristen (Obolevitch, 2015, p. 210; Rojek, 2016, pp. 149-150).

Dengan demikian, Rojek (2016, p. 150) mengatakan imanlah yang biasanya mencari rasionya (premis). Dalam hal pertama, iman memerlukan dibenarkan atau dibuktikan melalui rasio, dalam hal yang kedua, yang tidak terlihat, iman memiliki prioritas absolut dan menerangi pikiran alami itu sendiri. Filsafat hendaknya tidak berusaha untuk membumikan teologi yang merumuskan argumen-argumen untuk eksistensi Tuhan atau membuktikan koherensi teisme, tetapi menerima teologi sebagai premis fundamental dan kemudian mengembangkan suatu yang baru serta "non-sekuler" untuk topik-topik filosofis lama.

\section{Filsafat dan Teologi sebagai Wawasan Dunia Kristen}

Lebih lanjut lagi, hal yang perlu diperhatikan adalah hubungan filsafat dan teologi sebagai wa- wasan dunia Kristen. Nash (Nash, 2013, pp. 15-16) dalam bukunya, Iman dan Akal Budi, menyatakan bahwa pemikiran filsafat adalah hal yang dilakukan oleh setiap orang yang dewasa dan rasional, sekalipun pada faktanya hanya sedikit yang menjadi filsuf profesional. Selanjutnya, ia menyatakan bahwa seseorang yang memiliki sistem filsafat ialah mereka yang mempunyai suatu pandangan dunia (worldview) tertentu. Dan kekristenan juga merupakan pandangan hidup dan dunia secara keseluruhan (David A. Noebel, 2001, pp. 2-10; Nash, 2013, p. 38). Berdasarkan pernyataan tersebut, maka teologi yang merupakan bagian dari kekristenan serta filsafat dapat dijadikan sebagai kerangka keyakinan untuk membangun wawasan dari dunia Kristen (David A. Noebel, 2001, pp. 375-388; Doherty, 2018, p. 278).

Geisler dan Feinberg (2002, p. 478) mendefinisikan "wawasan dunia" diartikan sebagai "bagaimana seseorang memandang atau menafsirkan realita... ini merupakan kerangka, yang melalui atau oleh seseorang membuat pengertian dari data kehidupan." Selanjutnya, senada dengan hal tersebut, Moreland dan Craig (2003, pp. 404, 421) juga mendefinisikan worldview (pandang-dunia) seluruh pandangan dunia adalah evaluasi dari jawaban yang diberikan oleh teori atau pandangan dunia terhadap pertanyaan tersebut, yang dimana jawaban tersebut masuk akal. Pemikiran tersebut dapat ada karena manusia mengetahui bahwa mereka memiliki cara pandang yang berbeda satu dengan yang lain mengenai realitas yang ada. Oleh sebab itu, sangat perlu untuk melihat realitas dengan sudut pandang yang benar agar apa yang terlihat benar-benar sebagaimana mestinya. Untuk itu diperlukan suatu sudut pandang yang kristiani.

Kemudian, Nash (2013, pp. 43-47) dalam bukunya yang sama, menunjukkan bahwa kerangka keyakinan yang membangun suatu wawasan dunia secara umum adalah: hal mengenai Allah (teologi), kenyataan (metafisik), pengetahuan (epistemologi), moralitas (etika) dan manusia (antropologi). Ini menunjukkan bagaimana filsafat dan teologi merupakan bagian dari wawasan dunia. Dalam konteks kekristenan, maka diperlukan suatu hal yang khusus, yaitu 
'wawasan dunia Kristen'. Teologi injili secara khusus dalam wawasan dunia Kristen dapat dipahami pokok-pokok isinya, sebagai berikut (David A. Noebel, 2001; Nash, 2013, pp. 51-68): Pertama, Teologi. Wawasan dunia Kristen merupakan sebuah teistik dalam artian wawasan dunia ini percaya akan adanya satu Allah yang penuh kuasa dan berpribadi. Teisme teologi injili bersifat trinitarian, yaitu menganut doktrin Trinitas yang merefleksikan keyakinan Kristen bahwa Bapa, Putra dan Roh Kudus merupakan tiga pusat kesadaran yang berbeda yang secara utuh berbagi di dalam satu natur ilahi dan di dalam aktifitas setiap pribadi trinitas. Satu kesimpulan penting doktrin ini terhadap keyakinan Kristen yaitu bahwa Yesus Kristus adalah sepenuhnya Allah dan sepenuhnya manusia. Kedua, Metafisik. Prinsip metafisik penting wawasan dunia Kristen ada pada pernyataan yaitu bahwa Allah menciptakan dunia ex nihilo (dari yang tidak ada, Kej. 1:1). Dalam catatan teologi injili tentang penciptaan, tidak ada satu pun yang eksis sebelum penciptaan kecuali Allah. Tak ada ruang atau waktu juga tak ada material yang mendahului. Segala sesuatu yang eksis selain Allah benar-benar bergantung pada Allah untuk eksistensinya. Ketiga, Epistemologi. Dalam perspektif teologi injili, wawasan dunia Kristen yang baik tidak akan memasukkan di dalamnya pernyataan yang mengatakan bahwa manusia tidak dapat mencapai pengetahuan tentang Allah. Teologi injili jelas-jelas mengatakan bahwa Allah telah menyatakan diri-Nya. Keempat, Etika. Manusia menjadi bermoral sebab diciptakan segambar dengan Allah (berpikir, mengasihi dan mempunyai kesadaran akan Allah). Dosa telah mendistorsi gambar dan rupa Allah tersebut, sehingga seringkali manusia berpaling dari Allah dam hukum moral. Kelima, Antropologi. Wawasan dunia Kristen mengetahui kebutuhan manusia akan pengampunan, penebusan dan beberapa penekamam bahwa berkat keselamatan bisa terjadi karena kematian dan kebangkitan Yesus. Wawasan dunia dalam perspektif injili mengajarkan bahwa kematian fisik bukanlah akhir dari eksistensi seseorang.
Dari hal tersebut, maka dapat terlihat dengan jelas bahwa filsafat dan teologi dapat dijadikan kerangka bagi wawasan dunia Kristen. Sebab dua-duanya ada di dalam wawasan dunia dunia baik secara umum maupun secara Kristen. Namun demikian, di dalam pembahasan ini lebih melihat dari perspektif teologi injili. Sehingga, jika keduanya sama-sama dipadukan dan digunakan sesuai dengan tempat yang tepat akan dapat menghasilkan sesuatu yang indah bagi kehidupan orang-orang percaya, yaitu melihat segala realita yang ada di dunia ini dengan tepat dan benar dalam kerangka wawasan dunia Kristen. Penekanan teologi injili pada memberitahukan kebenaran yang dapat dimengerti dan menjelaskan ulang dalam relasi proses dimana manusia mengerakkan dari apa yang dilihat kepada menjadi apa yang manusia bawa (Peperzak, 1997, pp. 332-333; Platinga, 1999, p. 103; Ronda, 2005, pp. 12-16).

Dengan demikian, wawasan dunia Kristen dalam perspektif teologi injili merupakan suatu pijakan dan cara memandang seseorang dari perspektif iman Kristen. Orang yang beriman sudah tentu akan memiliki filsafat kristiani yang di dasarkan pada firman Allah, yaitu Alkitab.

Melihat relasi di atas, filsafat dan teologi melestarikan "otonomi esensial" mereka sambil menemukan pemenuhannya hanya dalam kerja sama yang erat, dalam "koneksi yang tidak dapat dibatalkan"; oleh karena itu, masing-masing mempertahankan keaslian dan karakter aslinya, usaha filosofis dan teologis saling memperkaya dan mencerahkan satu sama lain dengan yang lain. Simbiosis nyata dari filsafat dan teologi, diperlukan, yang merupakan antipode dari kecenderungan untuk memisahkan filsafat dan teologi, dimanifestasikan baik dengan para bapa gereja (Paulus, Agustinus, Origenes dan lainnya), yang melihat skandal dalam gagasan persahabatan dengan yang ilahi, dan dalam pencerahan berupaya mengungkap prinsip-prinsip teologi yang benar hanya dalam akal manusia, dan dengan demikian menolak kontingensi historis dan kekhasan wahyu yang benar. Visi saling ketergantungan antara filsafat dan teologi ini merupakan bagian integral dari 
dialektika (Brandt et al., 2018, p. 147; Doherty, 2018, p. 279).

\section{KESIMPULAN}

Pada bagian kesimpulan ini, penulis merefleksikan relasi antara filsafat dan teologi, yaitu keduanya adalah dua sarana yang dianugerahkan Allah kepada manusia, sehingga manusia dapat memahami dan mengenal siapa diri-Nya dan hal-hal yang berkaitan dengan-Nya. Dalam perspektif teologi injili, kedua hal tersebut tidak jarang berseberangan, sehingga menghasilkan sesuatu yang perdebatan yang serius. Keduanya diusahakan untuk dapat berdampingan dan menajamkan di dalam kekristenan. Oleh sebab itu, dapat dikatakan bahwa filsafat dan teologi adalah sesuatu yang netral dan tergantung kepada siapa yang mempergunakannya. Dapat diibaratkan seperti 'pisau', yang dapat digunakan untuk memasak sesuatu yang indah bila berada di tangan seorang koki, namun juga dapat digunakan untuk membunuh jika berada di tangan orang yang jahat.

Keilmuan filsafat dan teologi saling menguatkan dan menajamkan. Otonomi filsafat yang sesungguhnya dijamin hanya dengan mengakui ketidakmampuannya untuk menjawab pertanyaan-per-

\section{DAFTAR RUJUKAN}

Anthony, K. I. (2014). The Meaning and Nature of African Philosophy in a Globalising World. International Journal of Humanities Social Sciences and Education, 1(7), 86-94.

Brandt, R. A., Diffey, D. S., Kelley, A. O., Burnette, D., Greever, J. M., Frederick, J., \& Irons, C. L. (2018). Journal of Biblical and Theological Studies. 3(1).

Brown, C. (1994). Filsafat \& Iman Kristen (3rd ed.). Surabaya: Momentum.

David A. Noebel. (2001). The Battle for Truth: Defending the Christian Worldview in the Marketplace of Ideas. Eugene: Harvest House Publishers.

Diller, K. (2010). Karl Barth and the relationship between philosophy and theology. Heythrop tanyaan yang hanya bisa dijawab oleh teologi: non adjutrix nisi libera; non libera nisi adjutrixosophia (filsafat bukan penolong kecuali itu bebas dan tidak bebas kecuali itu penolong). Dalam saling ketergantungan ini, tidak ada disiplin yang melepaskan otonominya atau mengubah fungsi dasarnya sebagai penyelidikan rasional. Sebaliknya, masing-masing berkontribusi pada "simbiosis" menguntungkan dengan yang lain. Dengan demikian filsafat dan teologi seharusnya berada dan takluk di bawah Kristus. Sehingga, setiap filsuf atau teolog seharusnya berteologi dan berfilsafat dengan sikap rasa takut akan Allah, untuk mendapatkan dan memahami kebenaran yang sejati tentang Allah dan hal-hal yang berkaitan dengan-Nya.

Selain itu, refleksi filsafat dan teologi dimana masing-masing adalah ada di dalam diri manusia sebagai manusia ciptaan Allah yang serupa dan segambar dengan Dia. Oleh sebab itu, keduanya sudah seharusnya direlasikan dalam kondisi yang harmonis, yaitu bukan saling bertentangan, melainkan saling membangun dalam tugasnya sebagai sarana pengenalan akan Allah serta sebagai kerangka untuk membangun teologi.

Journal - Quarterly Review of Philosophy and Theology, 51(6), 1035-1052. https://doi.org/10.1111/j.1468-

2265.2009.00521.x

Doherty, C. (2018). The Symbiosis of Philosophy and Theology in Blondel's Supernatural Hypothesis. Theological Studies, 79(2), 274-293.

https://doi.org/10.1177/0040563918766695

Erickson, M. J. (1999). Teologi Kristen. Malang: Gandum Mas.

Gaston, T. E. (2009). The influence of platonism on the early apologists. Heythrop Journal Quarterly Review of Philosophy and Theology, 50(4), 573-580. https://doi.org/ $10.1111 / \mathrm{j} .1468-2265.2008 .00448 . x$ 
Geisler, Norman L; Feinberg, P. D. (2002). Filsafat Dari Perspektif Kristiani (2nd ed.). Malang: Gandum Mas.

Hadiwijono, H. (2014). Sari Sejarah Filsafat Barat 1. Yogyakarta: Kanisius.

Holmes, A. F. (2009). Segala Kebenaran adalah Kebenaran Allah. Surabaya: Momentum.

Knight, G. R. (2006). Philosophy and Education An Introduction in Christian Perspective. Berien Springs: Andrews University Press.

Lukito, D. L. (2002). Pengantar Teologia Kristen 1. Bandung: Yayasan Kalam Hidup.

Macintyre, A. (2009). God, Philosophy, Universities. Lanham, MD: Rowman \& Littlefield.

Michaud, N. (2015). Why Philosophy is Important for Administrators in Education. Journal of Inquiry and Action in Education, 6(3), 4.

Moreland, J.P; Craig, W. L. (2003). Philosophical Foundations for a Christian Worldview. Downers Grove, IL: InterVarsity Press.

Nash, R. H. (2013). Iman \& Akal Budi. Surabaya: Momentum.

Obolevitch, T. (2015). Faith and Knowledge in the Thought of Georges Florovsky. In Teresa Obolevitch and Paweł Rojek (Ed.), Faith and Reason in Russian Thought. Krakow: Copernicus Center Press.

Peperzak, A. (1997). Philosophia. 14(3).

Platinga, T. (1999). Christian Philosophy Within Biblical Bounds. Alberta, Canada: Inheritance Publication.

Rahmat, P. S. (2009). Penelitian Kualitatif. Journal Equilibrium, pp. 1-8.

Reynold, J. M. (2009). When Met Jerusalem: An Introduction to Classical and Christian Thought (16th ed.). Downers Grove, IL: InterVarsity Press.

Rojek, P. (2016). Intellectus quaerens fidem: Georges Florovsky on the relation between philosophy and theology. Roczniki Filozoficzne, 64(4), 149-165. https://doi.org/ 10.18290/rf.2016.64.4-8

Ronda, D. (2005). Prospek Teologi sebagai Ilmu. Jurnal Jaffray, 2(2), 12. https://doi.org/ 10.25278/jj71.v2i2.156

Santrac, A. S. (2013). Three I know not what:The influence of Greek philosophy on the doctrine of Trinity. In Die Skriflig/In Luce Verbi, 47(1), 1-7. https://doi.org/10.4102/ids.v47i1.719

Stumpf, Samuel Enoch; Fieser, J. (2003). Socrates to Satre and Beyond: A History of Philosophy. New York: McGraw-Hill.

Suriasumantri, J. S. (2009). Filsafat Ilmu: Sebagai Pengantar Populer. Jakarta: Pustaka Sinar Harapan.

Susilowati. (2017). Kegiatan Humas Indonesia Bergerak Di Kantor Pos Depok II Dalam Meningkatkan Citra Instansi Pada Publik Eksternal. Jurnal Komunikasi, VIII (September), 47-54.

Tety, \& Wiraatmadja, S. (2017). Prinsip-prinsip filsafat pendidikan Kristen. Evangelikal: Jurnal Teologi Injili Dan Pembinaan Warga Jemaat, 1(1), 55-60.

Waltke, B. K. (2004). The Book of Proverbs. Grand Rapids, Michigan: William. B. Eerdmans Publishing.

Warfield, Benjamin B.; Brown, William Adams; Smith, G. B. (1910). The Task and Method of Systematic Theology. The American Journal of Theology, 14(2), 192-233.

Wippel, J. F. (1984). The Possibility of a Christian Philosophy. Faith and Philosophy, 1(3), 272-290.

https://doi.org/10.5840/faithphil19841320 